\title{
PERANAN BUMDES DALAM MENGGALI POTENSI DESA DENGAN MEMANFAATKAN KEARIFAN LOKAL (Study Kasus Pada Bumdes Mukti Bersama Desa Sido Mukti Kecamatan Plakat Tinggi Kabupaten Musi Banyuasin)
}

\author{
Masri Ermawijaya \\ STIE Rahmaniyah Sekayu \\ Email : masriermawijava60@gmail.com
}

\begin{abstract}
Abstrak
Peneltian ini bertujuan untuk mengetahui peran Badan Usaha Milik Desa (BUMDes) Mukti Bersama Desa Sidomukti Kecamatan Plakat Tinggi Kabupaten Musi Banyuasin dalam menggali potensi desa dengan memanfaatkan kearifan lokal. Metode yang digunakan dalam penelitian ini dengan metode deskriptif kualitatif. Data yang digunakan adalah data primer dan data sekunder berupa laporan pertanggungjawan kegiatan dan keuangan BUMDes. Teknik pengumpulan data dengan cara observasi, wawancara, dokumentasi dan studi pustaka. Hasil pembahasan menunjukkan bahwa BUMDes Mukti Bersama Desa Sidomukti Kecamatan Plakat Tinggi sangat berperan dalam meningkatkan perekonomian masyarakat dengan menggali potensi desa yang tersedia, Peran BUMDes terkait aspek pelayanan berimplikasi terhadap kemandirian ekonomi desa, terkait aspek akuntabilitas berimplikasi terhadap meningkatnya Pendapatan Asli Desa (PADes), terkait aspek peningkatan taraf hidup berimplikasi terhadap pertumbuhan dan pemerataan ekonomi pedesaan, dan terkait aspek ketaatan peraturan perundang-undangan berimplikasi pada pengelolaan potensi desa dalam memenuhi kebutuhan masyarakat yaitu kredit kebutuhan rumah tangga, alat tulis sekolah kerjasama dengan BRIlink dan PT MEP untuk layanan listrik/token. Namun dalam pelaksanaan kegiatan BUMDes terkendala pada permodalan yang masih mengandalkan dana desa untuk membiayai kegiatannya, pemanfaatan kearifan lokal sumberdaya desa yang masih kurang tergali Upaya yang dilakukan BUMDes Mukti Bersama harus dapat mengatur pendapatan dan keuntungan sehingga ketergantungan dengan dana desa atau hibah dari Kemendesa PDTT dapat dilepas sehingga akan mendorong BUMDes secara mandiri dan bertanggungjawab menggali potensi desa lainnya.
\end{abstract}

Kata kunci : BUMDes, Potensi Desa, Kearifan lokal

\section{Pendahuluan}

Pembangunan di desa perlu diprioritaskan dalam upaya perbaikan perekonomian desa dan dapat meningkatkan kemandirian masyarakat serta mengentaskan kemiskinan. Dalam pengentasan kemiskinan, Negara Indonesia memiliki bermacam strategi salah satunya adalah pemberdayaan masyarakat yaitu dengan memaksimalkan masyarakat itu sendiri 
Dalam upaya pembangunan desa harus dilakukan secara berencana dan menyentuh kebutuhan riil masyarakat desa, oleh karena itu pembangunan desa harus didasarkan pada potensi desa dan kelemahan desa. Atas dasar kepentingan masyarakat ini maka desa harus dapat mengembangkan potensi yang ada yang nantinya akan dinikmati oleh masyarakat desa itu sendiri.

Desa menjadi ujung tombak pembangunan Indonesia. Oleh karena itu pemerintah terus berupaya mendorong ekonomi desa dengan penyaluran Dana Desa dan program pengembangan Badan Usaha Milik Desa (BUMDes). Tujuan BUMDes seperti dalam Permendesa PDTT dan Transmigrasi Nomor 4 Tahun 2015 adalah, meningkatkan perekonomian desa, meningkatkan usaha masyarakat dalam pengelolaan potensi ekonomi desa.

BUMDes dibangun atas prakarsa (inisiasi) masyarakat desa, serta mendasarkan pada prinsip-prinsip kooperatif, partisipatif, (user-owned, userbenefited, and user-controlled), transparansi, emansipatif, akuntable, dan sustainable dengan mekanisme member-base dan self-help. Dari semua itu yang terpenting adalah bahwa pengelolaan BUMDes harus dilakukan secara profesional dan mandiri.

Badan Usaha Milik Desa (BUMDes) merupakan pilar kegiatan ekonomi di desa yang berfungsi sebagai lembaga sosial (social institution) yang berarti BUMDes memberikan dampak langung dalam hal pembinaan dan pendampingan usaha bagi masyarakat desa dan secara tidak langusng menambah Pendapatan Asli Desa (PADes) dan komersial (commercial institution) bertujuan mencari keuntungan melalui penawaran sumber daya lokal (baik barang maupun jasa) ke pasar.

Salah satu tujuan BUMDes didirikan adalah untuk penopang atau penguat ekonomi desa. Desa Sidomukti Kecamatan Plakat Tinggi yang secara gografis memiliki luas tanah $247 \mathrm{Km}$, yang terdiri dari dataran tinggi dan perbukitan. jumlah penduduk pada tahun 2020 mencapai 26.743 jiwa (BPS Kabupaten Musi Banyuasin). Kecamatan Plakat Tinggi penduduknya Sebagian besar berasal dari warga transmigrasi akibat bencana Gunung Galunggung di Jawa Barat. Pada zaman orde baru sesuai dengan rencana pemerintah pusat transmigran ini disediakan lahan untuk bercocok tanam untuk menopang ekonomi keluarga. Seiring waktu dengan 
kesuburan tanah dan kegigihan masyarakat di kecamatan Plakat Tinggi maka pertanian dan perkebunan mengalami peningkatan yang pesat sehingga beberapa perusahaan sawit dan karet menjadikan Kecamatan Plakat Tinggi sebagai salahsatu penyumbang pendapatan tertinggi pada komoditi Karet, Sawit hal ini memberikan kontribusi yang cukup besar bagi Kabupaten Musi Banyuasian.

Kecamatan Plakat Tinggi adalah salah satu kecamatan di Kabupaten Musi Banyuasin terdiri 15 Desa, yang penduduknya sangat tergantung pada sektor pertanian dan perkebunan yang dikelola baik secara mandiri maupun dengan plasma dari perusahaan perkebunan swasta.

Berbagai upaya pengembangan potensi desa yang dilakukan pemerintah kecamatan Plakat Tinggi dalam meningkatkan ekonomi pedesaaan mulai dari pendirian Koperasi dan Usaha Kecil Mikro, pemanfaatan lahan bukit yang tanahnya dapat dijual sebagai tanah timbunan dan pemanfaatan potensi desa lainnya yang dapat memberikan kontribusi bagi desa setempat,

Salah satu Desa di Kecamatan Plakat Tinggi yaitu Desa Sidomukti (Satuan pemukiman 1/SP1) dalam menggali potensi desa sesuai dengan kebutuhan riil penduduknya maka berdirilah BUMDes Mukti Bersama Desa Sidomukti Kecamatan Plakat Tinggi Kabupaten Musi Banyuasin Provinsi Sumatera Selatan pada tanggal 16 Desember 2016. Tujuan berdirinya BUMDes ini adalah dalam rangka memenuhi kebutuhan masyarakat terutama masyarakat yang membutuhkan dana untuk pengembangan pertanian, pemenuhan kebutuhan rumah tangga, pembayaran rekening listrik dan air serta kebutuhan komunikasi (pulsa telepon). Atas dasar inilah dengan pengalokasian dana Desa Sidomukti dialokasikan dari dana desa untuk BUMDes Mukti Bersama sampai dengan tahun 2019 sebagaimana terlampir dalam tabel 1 berikut ini :

Tabel 1

Alokasi Dana Desa dan Laba BUMDes Mukti Bersama Tahun 2017 s.d. 2021

Desa Sidomukti Kecamatan Plakat Tinggi

Kabupaten Musi Banyuasin Provinsi Sumatera Selatan

\begin{tabular}{|c|c|c|c|}
\hline TAHUN & SUMBER DANA & JUMLAH & LABA \\
\hline 2017 & DD 2014 & Rp. 109.000 .000 & $\mathrm{Rp}, 27.751 .000$ \\
\hline
\end{tabular}




\begin{tabular}{|c|l|l|l|}
\hline TAHUN & \multicolumn{1}{|c|}{ SUMBER DANA } & \multicolumn{1}{|c|}{ JUMLAH } & LABA \\
\hline 2017 & DD 2017 & Rp. 123.445.000 & \\
\hline 2017 & Hibah Kemendesa PDTT & Rp. 50.000.000 & \\
\hline 2018 & DD 2018 & Rp. 80.000 .000 & Rp. 25.812.500 \\
\hline 2019 & DD 2019 & Rp. 50.000.000 & Rp. 26.215.058 \\
\hline 2020 & - & - & Rp. 21.879.675 \\
\hline 2021 & - & - & Rp. 21.786.666 \\
\hline
\end{tabular}

Sumber : Laporan Pertanggungjawaban BUMDes Mukti Bersama, 2022

Berdasarkan tabel 1 diatas bahwa sumber pendanaan dari taun 2017 s,d, 2019 masih tergantung dari dana desa dan belum mengoptimalkan secara mandiri pemanfaatan dan pengembangan usaha yang telah digerakkan oleh BUMDes Mukti Bersama Desa Sidomukti Kecamatan Plakat Tinggi Kabupaten Musi Banyuasin, namun pemberian dana ini telah menghasilkan peningkatan keuntungan bagi BUMDes Mukti Bersama yang berarti potensi yang ada betul-betul digali dengan cara baik. Tahun 2020 dan 2021 Dana Desa dialihkan untuk menangani COVID19, namun keuntungan yang diperoleh BUMDes Mukti Bersama cukup stabil dari tahun sebelumnya. Hal ini menunjukkan bahwa manajemen BUMDes Mukti Bersama telah berusaha memanfaatkan modal yang ada dan sisa keuntungan tahuntahun sebelumnya secara optimal. Kegiatan usaha yang dilakukan tidak hanya kredit jasa mikro seperti pemenuhan kebutuhan rumah tangga, kredit alat tulis bagi sekolah dengan berkerjasama dengan BRI sebagai salahsatu agen BRILink untuk kredit dan pembayarannya.juga kerjasama dengan PT MEP sebgaai agen penjualan listrik/token.

Kearipan lokal yang dimaksud sesuai amanat Undang-undang Nomor 32 Tahun 2009 adalah nilai-nilai luhur yang berlaku dalam tatanan kehidupan masyarakat antara lain untuk melindungi dan mengolah lingkungan hidup secara lestari. Dengan dasar inilah maka BUMDes Mukti Bersama Desa Sido Mukti Kecamatan Plakat Tinggi Kabupaten Musi Banyuasin Provinsi Sumatera Selatan mengupayakan agar dapat berperan meningkatkan ekonomi desa melalui peningkatan PADes, yang nantinya akan memberikan dampak pada kesejahteraan 
masyarakat setempat, membuka lapangan kerja dan berkontribusi dalam peningkatan ekonomi masyarakat.

BUMDes Mukti Bersama Desa Sido Mukti Kecamatan Plakat Tinggi Kabupaten Musi Banyuasin Provinsi Sumatera Selatan sampai saat ini telah terkumpul modal sebesar Rp 395.052.121, Dalam tahun 2020 BUMDes Mukti Bersama ini telah merealisasikan Kerjasama dengan PDAM Tirta Randik membuat jaringan pipa distribusi air bersih ke rumah-rumah masyarakat yang sudah mendaftar sebagai calon pelanggan di BUMDes Mukti Bersama . Saat ini sudah terdapat calon pelanggan sebanyak 210 keluarga yang bergabung dengan BUMDes dari 700 keluarga. Dan Pengembangan kolam milik desa yang rencananya akan diberdayakan sebagai wisata pemancingan di desa Sidomukti. Selain kolam milik desa, juga akan dikelola kolam masyarkat yang tidak diisi ikan karena kekurangan modal. Kolam masyarakat ini akan dikelola oleh BUMDes Mukti Bersama dengan perjanjian bagi hasil dengan pemilik lahan.Rencana lain yang akan dikembangkan oleh BUMDes Mukti Bersama adalah membina pengrajin gaplek dan jajanan berasal dari ubi kayu seperti kripik ubi yang bahan bakunya singkong yang banyak dihasilkan di desa ini dengan harapan harga jual singkong akan lebih tinggi sehingga keuntungan yang diperoleh petani dan BUMDes juga akan bertambah baik.

\subsection{Rumusan Masalah}

Berdasarkan latar belakang di atas, dapat dirumuskan permasalahan,sebagai berikut yaitu Bagaimana peran BUMDes Mukti Bersama dalam menggali potensi desa melalui pengembangan kearifan lokal bagi masyarakat Desa Sido Mukti Kecamatan Plakat Tinggi Kabupaten Musi Banyuasin Provinsi Sumatera Selatan.

\subsection{Tujuan Penelitian}

Berdasarkan rumusan masalah di atas, maka tujuan penelitian adalah untuk menjelaskan mendeskripsikan peran BUMDes Mukti Bersama dalam menggali potensi desa melalui pemanfaatan kearipan lokal, dalam hal ini pengembangan kolam milik desa untuk menjadi kolam pemancingan milik masyarakat Desa Sido Mukti Kecamatan Plakat Tinggi Kabupaten Musi Banyuasin Provinsi Sumatera Selatan, serta rencana pembinaan pengrajin gaplek dan jajanan berasal dari 
singkong seperti kripik ubi yang bahan bakunya singkong yang banyak dihasilkan di desa ini dengan harapan harga jual singkong akan lebih tinggi sehingga keuntungan yang diperoleh petani dan BUMDes juga akan bertambah.

\section{Landasan Teori}

\subsection{Pengertian Desa dan Permasalahannya}

Desa menjadi ujung tombak pembangunan Indonesia Masyarakat pedesaan juga kerap dihubungkan dengan masalah kemiskinan, serta masih terbatasnya akses untuk mendapatkan pelayanan dasar. Desa merupakan unsur terkecil dari sebuah negara, pada umumnya masyarakat pedesaan kerap melestarikan kearifan lokal yang tekait dengan nilai-nilai karakterisitik sosial, budaya dan geografis, struktur demografi, serta kelembagaan sosial. Desa memiliki peran penting dalam upaya pembangunan nasional hal ini dikarenakan posisi desa yang dianggap strategis karena desa dapat menjadi dasar dalam pengidentifikasian masalah masyarakat hingga perencanaan serta realisasi tujuan negara yang terdapat pada tingakat desa. Pembangunan pedesaan yaitu menempatkan desa menjadi sarana pembangunan agar tujuan untuk mengurangi berbagai kesenjangan dapat diwujudkan. Hal ini dikarenakan keberadaan desa masih dianggap tertinggal jika dibandingkan dengan perkotaan dari tingkat ekonomi, kesejahteraan, pendidikan dan fasilitas pendukung lainnya. Salah satu faktor penyebab kegagalan pembangunan di desa adalah masih banyaknya campur tangan dari pemerintah sehingga hal ini berdampak pada menurunnya tingkat kreativitas serta inovasi dari masyarakat desa dalam pengelolaan dan perekonomian desa.

Menurut Kushartono dalam Budiono (2015) cara yang dapat dilakukan untuk mendorong pembangunan di tingkat desa adalah pemerintah desa diberikan kewenangan oleh pemerintah pusat untuk mengelola secara mandiri lingkup desa melalui lembaga-lembaga ekonomi di tingkat desa. Salah satunya yaitu dengan membentuk Badan Usaha Milik Desa (BUMDes).

\subsection{Badan Usaha Milik Desa (BUMDes)}

Pembangunan pada hakekatnya bertujuan membangun kemandirian, termasuk pembangunan pedesaan. Salah satu misi pemerintah adalah membangun daerah pedesaan yang dapat dicapai melalui pemberdayaan masyarakat untuk 
meningkatkan produktivitas dan keanekaragaman usaha pedesaan, ketersediaan sarana fasilitas untuk mendukung ekonomi pedesaan, membangun dan memperkuat institusi yang mendukung rantai produksi dan pemasaran, serta mengoptimalkan sumber daya sebagai dasar pertumbuhan ekonomi pedesaan. Tujuannya adalah untuk memberi peluang bagi kemampuan daerah dan pedesaan sebagai tulang punggung ekonomi regional dan nasional. Kemajuan ekonomi nasional hanya akan tercapai jika terdapat iklim perekonomian yang baik di tingkat Provinsi. Kemajuan ekonomi di tingkat Provinsi akan tercapai jika Kabupaten memiliki kegiatan ekonomi yang baik. Kemajuan ekonomi sebuah Kabupaten dapat tercapai karena adanya sumbangsih dari ekonomi pedesaan yang kuat yang berimbas pada kesejahteraan masyarakat luas.

Badan Usaha Milik Desa (BUMDes) hadir sebagai suatu pendekatan baru sebagai usaha dalam meningkatkan dan memperkuat perekonomian desa berdasarkan kebutuhan dan potensi yang dimiliki desa. Berdasarkan Undang Undang Nomor 6 Tahun 2014 Tentang Desa dinyatakan bahwa BUMDes merupakan suatu badan usaha yang seluruh atau sebagian besar kepemilikan modalnya dimiliki oleh desa melalui penyertaan langsung yang berasal dari kekayaan desa yang dipisahkan guna mengelola aset, jasa pelayanan, dan usaha lainnya untuk kesejahteraan masyarakat desa yang sebesar-besarnya.

Pendirian BUMDes sebagaimana yang dimaksud dalam Permendesa PDTT Nomor 4 Tahun 2015 sebagai upaya menampung seluruh kegiatan dibidang ekonomi dan/atau pelayanan umum yang dikelola Desa dan/atau Kerjasama antarDesa. pendirian BUMDes merupakan jalan untuk membentuk ekonomi pedesaan yang mandiri sebagai upaya untuk meningkatkan Pendapatan Asli Daerah. Sebagai suatu badan usaha yang memihak kepada kepentingan masyarakat,

BUMDes mennjalankan kegiatan usahanya dengan berupaya memberikan pelayanan sosial dan ekonomi yang berorientasi pada profit oriented namun juga social benefit. Hal ini dapat dilakukan dengan memanfaatkan potensi yang ada di desa seperti sumber daya alam dan ekonomi. Namun potensi usaha tidak harus terfokus kepada sumber daya alam yang dimiliki karena tidak semua desa wilayahnya didukung oleh kekayaan alam. Hasil yang diperoleh dari BUMDes nantinya dapat digunakan untuk memberdayakan masyarakat. 


\subsection{Potensi Desa}

Potensi desa merupakan segala sumber daya alam maupun sumber daya manusia yang terdapat serta tersimpan di desa. Potensi desa adalah berbagai sumber alam (fisik) dan sumber manusia (non fisik) yang tersimpan dan terdapat di suatu desa, dan diharapkan kemanfaatannya bagi kelangsungan dan perkembangan desa. Adapun yang termasuk ke dalam potensi desa antara lain sebagai berikut :

\section{Potensi fisik}

Potensi fisik desa antara lain meliputi :

a. Tanah, dalam artian sumber tambang dan mineral, sumber tanaman yang merupakan sumber mata pencaharian, bahan makanan, dan tempat tinggal

b. Air, dalam artian sumber air, kondisi dan tata airnya untuk irigasi, persatuan dan kebutuhan hidup sehari-hari

c. Iklim, peranannya sangat penting bagi desa yang bersifat agraris.

d. Ternak, sebagai sumber tenaga, bahan makanan dan pendapat

e. Manusia, sebagai sumber tenaga kerja potensisal (potential man power) baik pengolah tanah dan produsen dalam bidang pertanian, maupun tenaga kerja industri di kota.

\section{Potensi Non Fisik}

Potensi non fisik desa antara lain meliputi :

a. Masyarakat desa, yang hidup berdasarkan gotong royong dan dapat merupakan suatu kekuatan berproduksi dan kekuatan membangun atas dasar kerja sama dan saling pengertian.

b. Lembaga-lembaga sosial, pendidikan, dan organisasi-organisasi sosial yang dapat memberikan bantuan sosial dan bimbingan terhadap masyarakat.

c. Aparatur atau pamong desa, untuk menjaga ketertiban dan keamanan demi kelancaran jalannya pemerintahan desa.

Kaitan potensi desa dalam perkembangan desa dan kota, antara lain :

1. Desa sebagai sumber bahan mentah maupun bahan pangan bagi kota

2. Desa berfungsi sebagai sumber tenaga kerja bagi kota

3. Desa sebagai mitra pembangunan bagi kota 
Potensi desa di setiap daerah berbeda satu sama lain karena faktor beriku : Keadaan Lingkungan Geografis, Jumlah dari penduduk desa, Luas tanah yang bisa digunakan, Jenis dan juga tingkat kesuburan tanah.

\subsection{Kearifan Lokal}

Kearifan lokal merupakan ciri khas etika dan nilai budaya dalam masyarakat lokal yang diturunkan dari generasi ke generasi. Kearifan lokal adalah identitas atau kepribadian budaya sebuah bangsa yang menyebabkan bangsa tersebut mampu menyerap, bahkan mengolah kebudayaan yang berasal dari luar/bangsa lain menjadi watak dan kemampuan sendiri. Kearifan lokal juga merupakan ciri khas etika dan nilai budaya dalam masyarakat lokal yang diturunkan dari generasi ke generasi.

Selanjutnya Istiawati (2016:5) berpandangan bahwa kearifan lokal merupakan cara orang bersikap dan bertindak dalam menanggapi perubahan dalam lingkungan fisik dan budaya. Suatu gagasan konseptual yang hidup dalam masyarakat, tumbuh dan berkembang secara terus-menerus dalam kesadaran masyarakat dari yang sifatnya berkaitan dengan kehidupan yang sakral sampai dengan yang profan (bagian keseharian dari hidup dan sifatnya biasa-biasa saja). Kearifan lokal atau local wisdom dapat dipahami sebagai gagasan-gagasan setempat. local yang bersifat bijaksana, penuh kearifan, bernilai baik, yang tertanam dan diikuti oleh anggota masyarakatnya.

Fungsi, karakteristik, dan ciri-ciri dari kearifan lokal. Fungsi kearifan lokal antara lain berfungsi untuk konservasi dan pelestarian sumber daya alam, pengembangan sumber daya manusia, pengembangan kebudayaan dan ilmu pengetahuan, sebagai petuah, kepercayaan, sastra dan pantangan. Bermakna sosial, misalnya upacara integrasi komunal atau kekerabatan dan pada upacara pertanian. Bermakna etika dan moral, yang terwujud dalam upacara hari besar umat beragama. Kearifan lokal dapat berbentuk nilai, norma, etika, kepercayaan, adat-istiadat, hukum, adat, aturan-aturan khusus.

\section{Metodologi Penelitian}

\subsection{Lokasi dan Waktu Penelitian}


Lokasi Penelitian dilakukan di Bumdes Mukti Bersama yang berlokasi di desa Sido Mukti Kecamatan Plakat Tinggi Kabupaten Musi Banyuasin Propinsi Sumatera Selatan. Waktu penelitian sejak awal bulan September 2021 sampai awal bulan Januari 2022.

\subsection{Jenis dan Sumber Data}

Metode penulisan ini merupakan suatu cara yang dilakukan untuk mencapai tujuan dalam suatu penulisan dengan menggunakan teknik dan alat-alat tertentu. Menurut Sanusi (2012:104), Ada dua jenis data yaitu data primer dan data sekunder. Pengertian data primer dan data skunder yaitu :

a. Data primer

Data primer adalah data yang pertama kali dicatat dan dikumpulkan oleh peneliti. Dalam hal ini data primer adalah data yang belum diolah yang dikumpulkan langsung dari objek yang diteliti, dalam hal ini data yang diperoleh dari pihak BUMDes Mukti Bersama Desa Sidomukti Kecamatan Plakat Tinggi berupa data unit usaha yang dijalankan, mekanisme dan administrasi untuk menjadi anggota BUMDes.

b. Data Sekunder

Data sekunder adalah data yang sudah tersedia dan dikumpulkan oleh pihak lain. Data ini diperoleh dengan cara membaca literatur-literatur yang ada hubungannya dengan masalah yang dianalisis. Laporan Pertanggungjawaban yang memuat tentang struktur organisasi, laporan kegiatan dan laporan keuangan.

\subsection{Teknik Pengumpulan Data}

Teknik yang digunakan Penulis untuk memperoleh dan mengumpulkan data penelitian ini, menurut Sugiyono (2010:37), yaitu :

\section{Studi Kepustakaan (Library Research)}

Teknik pengumpulan data yang dilakukan dengan mempelajari masalah yang berhubungan dengan objek penelitian yang bersumber dari buku-buku, undangundang, peraturan daerah dan Literatur-literatur yang berhubungan dengan 
penelitian dan penunjang atas dasar teori yang digunakan dalam permasalahan penelitian.

2. Studi Lapangan (Field Reserch)

Yaitu data yang dikumpulkan secara langsung dengan melihat objek penelitian di lapangan sesuai dengan keadaan yang akan diteliti. Adapun cara yang dipakai dalam penelitian lapangan ini adalah sebagai berikut :

a) Pengamatan (Observasi) yaitu dengan cara melakukan pengamatan langsung terhadap obyek yang diteliti.

b) Wawancara (Interview) yaitu dengan cara melakukan tanya jawab secara langsung dengan pihak-pihak yang dapat memberikan informasi dengan objek penelitian dengan berlandaskan pada tujuan penelitian.

c) Dokumentasi

Yaitu pengumpulan data dengan cara mengambil data-data yang berhubungan dengan masalah yang akan dibahas.

\subsection{Teknik Analisis Data}

Teknik analisis yang digunakan dalam penelitian ini adalah teknik analisis kualitatif. Menurut Sugiyono (2010:3), teknik analisis kualitatif yaitu suatu cara menganalisis data yang berupa informasi uraian sehingga mendapatkan gambaran pemecahan dari suatu permasalahan mulai dari pengumpulan data yang diperoleh, menyusun, mengelola dan menginterprestasikan data serta mengambil keputusan sehingga permasalahan dapat diselesikan.

\section{PEMBAHASAN}

\subsection{Peran BUMDes}

Dari seluruh penjabaran sebelumnya, diketahui bahwa peran BUMDes yang baik dapat ditinjau dari hubungan antara layanan, keuntungan, dan keberlangsungannya. Kualitas layanan yang diberikan pada masyarakat sangat mempengaruhi aspek yang lain. Dari pelayanan yang baik akan memicu masyarakat untuk ikut berpartisipasi pada BUMDes, kenaikan jumlah nasabah dan pelanggan juga akan mengakibatkan kenaikan pendapatan dan akhirnya keuntungan yang diperoleh juga akan mengalami kenaikan. Pendapatan dan keuntungan yang stabil dan terus meningkat akan menjaga keberlangsungan BUMDes itu sendiri. Namun, 
di sisi lain pelayanan BUMDes yang berazas kekeluargaan ini juga terkadang menimbulkan masalah, kemudahan-kemudahan yang diberikan pengurus BUMDes terkadang dinilai tidak sesuai standar operasional, dimana ketika proses pengajuan kredit kebutuhan rumah tangga dan Alat Tulis untuk sekolah yang ada di Desa Sidomukti di Kecamatan Plakat Tinggi, terkadang dokumen administrasi masih kurang lengkap namun proses tetap direalisasikan, Barang yang diminta untuk keperluan sekolah tidak sesuai dengan ketersediaan barang yang disediakan BUMDES Mukti Bersama, hal ini dikarenakan barang yang diminta oleh sekolah adalah bukan barang yang diual secara umum seperti Laptop, Hp, Printer dan sebagainya dan barang tersebut sifatnya material sehingga untuk menjual barang tersebut perlu dialkukan pemesanan terlebih dahulu sehingga BUMDes Mukti Bersama dapat merealisasikan, namun kadangkala mayarakat/sekolah minta nya segera sehinga BUMDes Mukti Bersama terkesan kurang memuhi keinginan mereka.

Langkah-langkah yang harus dilakukan oleh BUMDes Mukti Bersama Desa Sidomukti Kecamatan Plakat Tinggi untuk mengantisipasi permintaan dan pemenuhan kebutuhan masyarakat adalah :

1. Menyediakan Sistem dan Prosedur yang sederhana tentang proses pengajuan kredit sesuai dengan masing-masing unit usaha yang dijalankan, supaya alur administrasi dapat tertib dan rapi.

2. Adanya MoU atau Kerjasama dengan pemasok barang sehingga mendapatkan harga yang lebih rendah dari harga pasar (harga grosir).

3. Menjalin kerjasama dengan pemasok yang bersifat barang konsiyasi (titipan) sehingga mengurangi risiko rusaknya barang tersebut selama belum terdistribusikan.

4. Menyediakan Alat Tulis yang sesuai dengan permintaan sekolah/masyarakat

5. Untuk Barang-barang yang dikredit sebaiknya masyarakat Desa Sidomukti utntuk melakukan pemesanan terlebih dahulu sehingga keingnan dan kebutuhan dapat terlayanai oleh BUMDes Mukti Bersama,

Berikut Peran BUMDes Mukti Bersama Desa Sidomukti ditinjau dari berbagai aspek : 


\section{Peran BUMDes Mukti Bersama Ditinjau dari Akuntabilitas- Perkembangan Aset Desa}

Besar kecilnya pendapatan desa dipengaruhi oleh strategi yang dilakukan oleh BUMDes dalam mengelola dan memaksimalkan aset-aset yang ada di desa. Hal ini sejalan dengan PP No. 72 tahun 2005 pasal 78 yang menyatakan bahwa Badan Usaha Milik Desa (BUMDes) merupakan badan usaha yang dibentuk dalam rangka meningkatkan pendapatan asli desa. Menurut Hayyuna, dkk (2014), strategistrategi yang dilakukan untuk meningkatkan aset desa yaitu melalui mengamati lingkungan yang hasilnya dapat mengetahui potensi kegiatan usaha apa yang sesuai untuk diterapkan di BUMDes, adapun strategi yang dapat digunakan oleh BUMDes meliputi strategi pengembangan produk, penetapan harga, dan strategi keuangan dan lakukan evaluasi atau kontrol, yang dilakukan oleh Kepala Desa dikarenakan Kepala Desa Sidomukti Kecamatan Plakat Tinggi diberi wewenang oleh Pemerintah Daerah untuk mengawasi serta bertanggung jawab atas BUMDes di desa.

Dari uraian tersebut maka dapat disimpulkan bahwa strategi manajemen aset (peningkatan akuntabilitas) yang telah dilakukan oleh BUMDes telah berkontribusi sekaligus dapat meningkatkan pendapatan desa. Hal ini dapat dilihat dalam laporan pertanggungawaban kegiatan dan keuangan yang disusun oleh BUMDes Mukti Bersama Desa Sidomukti Kecamatan Plakat Tinggi.

\section{Peran BUMDes Mukti Bersama Ditinjau dari Peningkatan Taraf Hidup Dewan Direksi Pengawas dan Masyarakat}

Dengan terbentuknya BUMDes di desa-desa tentunya akan berpengaruh pada pendapatan masyarakat yang ikut andil dalam pengelolaan BUMDes, yang hakikatnya bertujuan untuk memenuhi kebutuhan masyarakat desa setempat. BUMDes diharapkan dapat memberikan manfaat sebesar-besarnya bagi kesejahteraan masyarakatnya, antara lain dapat menyerap tenaga kerja dari lingkungan desa setempat, sehingga menurunkan tingkat pengangguran di desa. Selain itu peningkatan pendapatan juga bagi pengurus BUMDes Mukti Bersama dengan pemberian insentif rutin dari BUMDes serta meningkatkan kompetensi pengurus dengan cara mengikutsertakan kegiatan pembibingan dan pelatihan yang berhubungan dengan teknologi informasi terbaru yang sesuai dengan aturan yang 
tertuang dalam Anggaran Dasar dan Rumah Tangga BUMDes, kegiatan ini dapat mendorong sumber daya yang ada menjadi lebih handal dan efesien.

\section{Peran BUMDes Mukti Bersama Ditinjau dari Ketaatan pada Peraturan dan Perundang- undangan}

Pengelolaan BUMDes yang baik, undang-undang dan peraturan pemerintah menjadi acuan untuk menjaga keberlangsungan dan peran BUMDes agar berjalan sesuai dengan ketetapan dan ketentuan yang berlaku. Dalam pelaksanaan operasional BUMDes Mukti Bersama Desa Sidomukti kecamatan Plakat Tinggi, berpedoman pada :

1. Undang-Undang Nomor 6 Tahun 2014 tentang Desa

2. Permendesa PDTT Nomor 4 Tahun 2015 tentang pendirian, pengurusan dan pengelolaan dan pembubaran BUMDes

3. Peraturan Pemerintah Nomor 11 Tahun 2021 tentang Badan Usaha Milik Desa

4. Dan peraturan perundang-undangan lainnya yang relevan

\section{Peran BUMDes dalam mendukung kemandirian ekonomi desa}

\section{a. Peran BUMDes Mukti Bersama dalam Meningkatkan Perekonomian Desa}

Dalam hal peran pelayanan BUMDes, diketahui terdapat perbedaan layanan antara BUMDes dan lembaga keuangan mikro lainnya di desa. Pelayanan BUMDes lebih menitikberatkan kemudahan dengan asas kekeluargaan dan kepercayaan untuk para nasabahnya. Sedangkan pada lembaga keuangan mikro lain harus dilaksanakan sesuai prosedur, tanpa ada pengecualian. Selain itu ditemukan bahwa layanan di BUMDes dilaksanakan dengan profesional dan fleksibel, prosedur yang digunakan lebih ringkas sehingga tidak membebani nasabahnya, kemudahankemudahan pada persyaratan pinjamannya serta tingkat bunga yang relatif rendah, selain itu Keuntungan BUMDes yang diterima dari usaha BUMDes yang lain seperti usaha-usaha riil yang dikelola oleh BUMDes tersebut. Usaha BUMDes pun dapat dibentuk sesuai potensi yang ada didesa, sehingga dapat memaksimalkan keunggulan dan keuntungan. Perkembangan usaha riil BUMDes ini pun berdampak pada masyarakat sekitar, usaha ini dapat menjadikan sumber penghasilan bagi beberapa masyarakat yang mengelola usaha-usaha BUMDes, sehingga peningkatan 
pelayanan, keuntungan dan keberlanjutan bagi BUMDes dalam peningkatan perekonomian desa.

\section{b. Peran BUMDes Mukti Bersama dalam Meningkatkan Pendapatan Asli Desa}

BUMDes Mukti Bersama Desa Sidomukti telah berkontribusi dalm meningkatkan pendapatan desa. Selain itu, BUMDes sudah dapat mewadahi program-program bantuan lainnya yang didapat dari pemerintah dan membantu mewadahi dana-dana program pemerintah yang masuk ke desa secara tidak langsung akan turut menjaga aset desa.Melalui program BUMDes ini telah menyumbang Pendapatan Asli Desa (PADes) peningkatan pendapatan desa.Dalam meningkatkan PADes masih terdapat beberapa hambatan dalam pengelolaannya, yaitu mengenai kesulitan dalam melakukan perkembangan usaha baru, terbatasnya inovasi dalam mengembangkan produk lokal, kurangnya sarana dan prasarana, rendahnya pengawasan dari Pemerintah Daerah.

\section{c. Peran BUMDes Mukti Bersama sebagai Tulang Punggung Pertumbuhan dan Pemerataan Ekonomi Pedesaan}

Diketahui bahwa peran BUMDes terkait Aspek Peningkatan Taraf Hidup Pengurus-Direksi-Masyarakat dinilai berimplikasi terhadap Kemandirian Ekonomi Masyarakat khususnya dalam hal kemampuan sebagai tulang punggung pertumbuhan dan pemerataan ekonomi pedesaan. Kemampuan menjadi Tulang Punggung Pertumbuhan dan Pemerataan Ekonomi Pedesaan yang dicapai BUMDes tersebut masih ditemukan kekurangan dalam pelaksanaannya, antara lain masih kurangnya sumber daya terdidik, terlatih dan profesional untuk mendukung diversifikasi usaha BUMDes pada sektor riil lainnya. Namun di sisi lain, manfaat tak langsung belum kelihatab, kurangnya minat, kemampuan, dan keberanian merupakan penyebab rendahnya jumlah masyarakat pekerja yang berani untuk berwirausaha sendiri sehingga baik dari pihak pengurus maupun pihak masyarakat masih kurang kesadaran dalam mewujudkan pemberdayaan masyarakat yang sesungguhnya di sektor riil dan usaha mikro yang harapannya adalah dalam rangka pemertaan ekonomi masayarakat di Desa Sidomukti Kecamatan Plakat Tinggi.

5. Peran BUMDes Mukti Bersama dalam Meningkatkan Pengolahan Potensi Desa sesuai dengan Kearifan Lokal dan Kebutuhan Masyarakat 
Peran BUMDes Mukti Bersama dalam pengolahan potensi desa disesuaikan dengan kebutuhan masyarakat yaitu menyediakan kredit mikro untuk kebutuhan rumah tangga, alat tulis sekolah, pembayaran rekening listri.token dan penyediaan air bersih dengan kerjasama BRI, PT MEP dan PDAM Tirta Randik. Usaha yang digunakan untuk menunjang kearifan lokal adalah dengan menggali potensi desa misal memnfaatkan kolam desa menjadi tempat wisata sekaligus kolam pemancingan. Menciptakan produk turunan dari singkong seperti pembuatan kripek dan lain-lain. Semua kegiatan ini diarahkan untuk meningkatkan ekonomi masyarakat, mengurangi pengangguran dan menambah pendapatan masyarakat dan desa Sidomukti kecamatan Plakat Tinggi.

\section{Simpulan dan Saran}

\subsection{Simpulan}

BUMDes Mukti Bersama Desa Sdomukti Kecamatan Plakat Tinggi telah turut andil dalam menggerakkan potensi desa yang berperan dalam mendukung kemandirian ekonomi desa yang berimplikasi dengan meningkatkan kesejahteraan masyarakat serta pendapatan bagi masyarakat dan Desa Sidomukti. Peran BUMDes terkait aspek pelayanan berimplikasi terhadap kemandirian ekonomi desa, peran BUMDes terkait aspek akuntabilitas berimplikasi terhadap meningkatnya Pendapatan Asli Desa, peran BUMDes terkait aspek peningkatan taraf hidup berimplikasi terhadap pertumbuhan dan pemerataan ekonomi pedesaan, dan peran BUMDes terkait aspek ketaatan peraturan perundang-undangan berimplikasi dalam kemampuan dalam pengelolaan potensi desa melalui BUMDes dalam bidang Jasa keuangan mikro yaitu kredit kebutuhan rumah tangga, Alat tulis untuk sekolah dan kerjasama dengan BRIlink untuk pelayanan kredit jasa mikro dan penjualan pulsa serta kerjasama dengan PT MEP untuk pembayaran rekening listrik/token..

\subsection{Saran}

Sehubungan dengan peran BUMDes Mukti Bersama Desa Sdomukti Kecamatan Plakat Tinggi dalam menggali potensi desa dengan pemanfaatan kearifan lokal dapat disarankan : 
1. BUMDes Mukti Bersama dalam menggali potensi desa melalui pengembangan kearifan lokal bagi masyarakat Desa Sidomukti Kecamatan Plakat Tinggi Kabupaten Musi Banyuasin Provinsi Sumatera Selatan, berupa rencana pengembangan kolam milik desa yang akan diberdayakan sebagai wisata pemancingan di desa Sidomukti. Selain kolam milik desa, juga akan dikelola kolam milik masyarakat yang tidak diisi ikan karena kekurangan modal. Kolam masyarakat ini akan dikelola oleh BUMDes Mukti Bersama dengan perjanjian bagi hasil dengan pemilik lahan. Rencana lain yang akan dikembangkan oleh BUMDes Mukti Bersama adalah membina pengrajin gaplek dan jajanan berasal dari singkong seperti kripik singkong yang bahan bakunya singkong yang banyak dihasilkan di desa Sidomukti ini dengan harapan harga jual singkong akan lebih tinggi sehingga keuntungan yng diperoleh petani dan BUMDes juga akan bertambah serta menjalin kerjasama dengan PDAM Tirta Randik Sekayu dalam rangka penyaluran air bersih bagi masyarakat Desa Sidodmukti Kecamatan Plakat Tinggi.

2. Peran Pelayanan, Keuntungan dan Keberlanjutan terkait standar operasional yang masih kurang baik, maka perlu ditingkatkan kualitas dan kuantitas pelatihan-pelatihan manajemen dan administrasi untuk para pengelola atau pengurus juga dilakukan pengawasan dari pihak di Badan Pemberdayaan Masyarakat Desa (BPMD), agar tetap tercipta standar pelayanan yang tetap fleksibel namun memiliki batasan-batasan tegas dan selektif serta mampu mencari solusi terbaik dari setiap kasus yang terjadi.

3. Peran Aspek Akuntabilitas dan Perkembangan Aset Desa terkait alokasi keuntungan terhadap PADes yang masih kurang, maka perlu dibuat suatu standar operasional, baik pada layanan, administrasi, maupun manajemen pada BUMDes, agar dana dari program-program lain yang diwadahi oleh BUMDes dapat terjaga dan meminimalisir hilangnya aset.

4. Peran Aspek Peningkatan Taraf Hidup terkait masih rendahnya minat, kemampuan dan kesadaran pengelola BUMDes dan masyarakat untuk berfokus pada pembangunan usaha sektor riil dan tidak hanya berfokus pada sektor kredit jasa mikro maka perlu diberikan sosialisasi pentingnya kemandirian berwirausaha pada masyarakat dan konsultasi mengenai potensi 
bisnis yang dapat dijalannya. Sehinga perlahan dapat mengubah pola pikir masyarakat pekerja untuk lebih berani membuka usaha baru.

5. Peran Ketaatan terhadap Peraturan Perundang-Undangan terkait tingkat pengembalian dana, maka pengurus BUMDes hendaknya lebih bijak dan bisa memilih prioritas, sehingga tidak ada dana yang terbuang percuma. Misal di sektor kredut perlu ada standarisasi persyaratan, prioritas, prosedur dan peraturannya yang harus dibuat untuk calon nasabah. Tujuannya menghindari kredit macet.

\section{DAFTAR PUSTAKA}

Anonim. Buku Panduan Pendirian dan Pengelolaan Badan Usaha Milik Desa (BUMDes). 2007. Surabaya. Departemen Pendidikan Nasional Pusat Kajian Dinamika Sistem Pembangunan (PKDSP) Fakultas Ekonomi Universitas Brawijaya.

Hayyuna R, Pratiwi RN, Mindarti LI. 2014. Strategi Manajemen Aset Bumdes Dalam Rangka Meningkatkan Pendapatan Desa (Studi Pada Bumdes Di Desa Sekapuk, Kecamatan Ujungpangkah, Kabupaten Gresik). Jurnal Administrasi Publik Volume 2 Nomor 1. Dunduh pada tanggal 1 Desember 2016.

Http://Administrasipublik.Studentjournal.Ub.Ac.Id/Index.Php/Jap/Article/View/33 $\underline{0}$

Istiawati, Fitri Novia.2016. Pendidikan karakter Nilai Nilai Kearifan Lokal Adat Ammato Dalam Menumbuhkan Karakter Koservasi. Jurnal Cendekia Vo.10 N0.1. Pusat Kajia Bahasa dan Budaya, Surakarta, Indonesia.

Peraturan Menteri Desa Pembangunan Daerah Tertinggal dan Transmigrasi Nomor 4 Tahun 2015 tentang pendirian, pengurusan dan pengelolaan dan pembubaran Badan Usaha Milik Desa.

Peraturan Pemerintah Nomor 11 Tahun 2021 tentang Badan Usaha Milik Desa

Peraturan Pemerintah Nomor 72 Tahun 2005 tentang Desa

Sanusi, Anwar. 2012. Metodologi Penelitian Bisnis. Jakarta Salemba Empat

Sugiyono. 2012. Metode Penelitian Kuantitatif Kualitatif dan R\&D. Bandung: Alfabeta.

Undang-Undang Republik Indonesia Nomor 22 Tahun 1999 tentang Pemerintahan Daerah.

Undang-Undang Republik Indonesia Nomor 32 Tahun 2004 tentang Pemerintahan Daerah. 
Jurnal Ilmiah Akuntansi Rahmaniyah (JIAR)

Vol. 5 No. 1, Desember 2021, 37 - 55

Ermawijaya

Undang-Undang Republik Indonesia Nomor 6 Tahun 2014 tentang Desa. 